\author{
Yaroslav Teleshun \\ Taras Shevchenko National University of Kyiv (Kyiv, Ukraine) \\ https://orcid.org/oooo-0oo1-8059-8791 \\ e-mail: teleshun.iaroslav@gmail.com
}

\title{
AGE OF MIDAS: NEW WORLD ORDER
}

\section{Abstract}

Corruption is an unchanging and «faithful» companion of the humanity accompanying it since ancient times. And like any product of mankind, it isn't a static phenomenon and develops in parallel with the complication of human relations. With the globalization the corruption has transformed and acquired new features that make it possible to classify it likes «global corruption». We assume that in today's world, global corruption is a stabilizing mechanism of the modern model of world order and a safeguard against the destruction of non-viable forms of human coexistence.

There are three main reasons for the inequality of income distribution in the world: 1) the existence of so-called «tax havens» - offshore zones that allow large-cap owners to avoid paying taxes; 2) inefficiency or unwillingness of national governments and the world community in regulating this issue; 3 ) the systematic business and politics interpenetration and the emergence of the newest phenomenon - the so-called «global corruption».

We argue that in such case post-Soviet States (including Ukraine and Russia) become a source and a «transit hub» for global corruption. Under the condition of systemic institutional instability existence, financial-industrial groups are losing exclusively economic features and getting new features, which allow them to be classified as financialpolitical groups. For such kind of corporate groups is typical the combination of economic, political, social and administrative components for the realization their private interests.

We propose two development scenarios of corruption interconnection between financial-industrial groups and public authorities in States with unstable institutional environment: 1) complete subordination of political and economic activities of financial-industrial groups to the will of the State- «occupation of business» (for example in the Russian Federation); 2) «seizure of power» by financial-industrial groups and their further transformation into financial-political groups (for example in Ukraine). We are convinced that in such circumstances corruption can be used by some Sates as an effective tool for the political process' influence of other countries.

Key words: corruption, oligarchs, financial-political groups, financial-industrial groups, unstable institutional environment, post-soviet space, Ukraine, Russian Federation. 


\section{Телешун Ярослав Сергійович}

Київський національний університет імені Тараса Шевченка (м. Київ, Украӥна) https://orcid.org/oooo-ooo1-8059-8791

e-mail: teleshun.iaroslav@gmail.com

\section{ДОБА МІДАСУ: НОВИЙ СВІТОВИЙ ПОРЯДОК}

\section{Резюме}

Корупція - незмінний i «вірний» супутник людства 3 давніх часів $\mathrm{i}$ по сьогоднішній день. Як і будь-яке явище, породжене людською діяльністю, корупція не є статичною та еволюціонує паралельно з ускладненням людських відносин. Під натиском глобалізації «традиційна» корупція набуває нових ознак, що дозволяють класифікувати її як «глобальну корупцію». Ми припускаємо, що в сучасному світі глобальна корупція є стабілізуючим механізмом сучасної моделі світового порядку та запобіжником руйнації нежиттєздатних форм людського співіснування.

Визначено три головні причини нерівності розподілу доходів у світі: 1) існування так званих «податкових раїв» - офшорних зон, що дають змогу власникам великого капіталу уникати сплати податків; 2) неефективність або небажання національних урядів і світового співтовариства у регуляції цього питання; 3) системне взаємопроникнення бізнесу й політики та виникнення явища так званої «глобальної корупції».

Стверджується, що держави з нестабільним інституційним середовищем, зокрема Україна й Російська Федерація, стали «транзитним хабом» глобальної корупції за посередництва фінансово-політичних груп. За умови існування системної інституційної нестабільності фінансово-промислові групи втрачають виключно економічні риси і набувають нових ознак, що дають підстави класифікувати їх як фінансово-політичні. Зазначено, що для таких корпоративних груп характерним $є$ поєднання економічних, політичних і адміністративно-управлінських складових для реалізації приватних та галузевих інтересів.

Запропоновано два характерних сценарії розвитку взаємозв'язку фінансово-промислових груп і органів державної влади в умовах нестабільного інституційного середовища: 1) повне підпорядкування політичної, 
економічної діяльності фінансово-промислових груп волі держави - «захоплення бізнесу» (наприклад, у Російській Федерації); 2) «захоплення влади» фінансово-промисловими групами та їхня подальша трансформація у фінансово-політичні групи (наприклад в Україні). Припущено, що за таких обставин деякі держави можуть використовувати корупцію як ефективний інструмент впливу політичного процесу на інші країни.

Ключові слова: корупція, олігархи, фінансово-політичні групи, фінансово-промислові групи, нестабільне інституційне середовище, пострадянський простір, Україна, Російська Федерація.

\section{Introduction}

«Money is freedom made of gold» Erich Maria Remarque

Today, at the beginning of the third millennium, it seems that legends, and even more so myths, are only a legacy of the mythological consciousness of the ancient times. However, myth, as a system of ideas about the world and the place of man in it, is an integral part of our lives today. Ancient mythologems, which seem to have long since sunk into oblivion, are being transformed and are receiving new sounds and meanings. After all, as the classic used to say, «Everything new is actually well-forgotten old». One such «new-old» myth is the legend of King Midas and his «golden touch». However, the bearer of this touch is no longer a half-legendary king, but his modern version, which is embodied in the so-called «collective Midas»-financial-political groups and the phenomenon of «global corruption».

At the turn of the XX-XXI centuries «global corruption», paradoxically, became a stabilizing mechanism of the modern world order model and a deterrent to the destruction of non-viable forms of human coexistence. The digital dictatorships, comprehensive and tireless propaganda, the "pandemic» of a damaging worldview (in response to globalization) have cast doubt on the apologists' assertions of the myth of an «ideal future». Which have either returned to nothingness or become a part of "global corruption», upholding the idea of competitiveness of the existing governance model and a viable social contract. Nevertheless, the crisis of human values, socio-political frustration and the request for search of the new forms of coexistence are asserting the opposite. In our estimation, to date, the phenomenon of «global corruption» accumulates between six to nine trillion dollars (based on the share of speculative transactions in the world). In particular, it is the "gray money» of Western countries, which is legalized in the transitional States through various funds, which promote the so-called «fake» models of governance. This necessitates the search for a new effective model of public administration that can take into account the interests of the State, key corporate actors, civil society and the individual. 
The manifestations of the current political governance crisis are reflected in mass protests of socio-economic and political nature in Lebanon, Chile, Iraq, Ecuador, France («Yellow Vest Movement»), Catalonia and Hong Kong; the results of the presidential elections in the United States, Ukraine, Tunisia, Brazil and permanent «electoral seismicity» in Spain and Israel; waves of «exits» led by the United Kingdom; further ideological polarization: the strengthening of right-wing populism in the European Union and the renaissance of left-wing politics ideas in the United States of America; numerous climate demonstrations in London, Paris, Brussels, Montreal; the paralysis of the public administration in the fight against the pandemic COVID-19, which ultimately puts on the agenda in front of the international community, national governments and the scientific community on the need to find new, competitive forms of human coexistence, qualitative governance models and a viable social contract.

\section{Research methods}

The wide range of quantitative, qualitative and mixed methods was used to solve the research problem. Historical method made it possible to analyze the historical preconditions and the process of formation of financial-industrial groups and their further transformation in financial-political groups both in Ukraine and Russian Federation. The casual-comparative method was used to analyze the domestic and foreign experience of the influence of financial-industrial / financial-political groups on the process of making public administration decisions. The structural-functional approach helped to identify the bilateral dependence of corporate entities and the establishment in unstable institutional systems (the formation of patron-client relations). Also these methods were used to study the corruption and its role like a stabilizing mechanism of the modern model of world order and a safeguard against the destruction of non-viable forms of human coexistence.

\section{Results and discussion}

The evidence of the inefficiency of the current model of social contract between authority, business and civil society may be a progressive inequality of income distributions in society and increasing big business impact on policymaking process. According to Oxford Committee for Famine Relief (Oxfam) study over the last decade, the number of billionaires has doubled and by the end of $2018^{\text {th }}$ their numbers have crossed the mark of two thousand (2028 billionaires) [21]. During 2017-2018 a new billionaire is announced every two days in the world with an average wealth increase of $\$ 2.5$ billion every day. Instead, the financial situation of the 3.8 billion (with a total human population of 7.7 billion) the poorest people have not improved in any way.

The threat of inequality of resources and income distributions in the world are recognized by experts and representatives of influential international institutions: the International Monetary Fund (IMF) and the Organization for 
Economic Co-operation and Development (OECD). According to the Managing Director of the International Monetary Fund Kristalina Georgieva: «Over the past decade, inequality has become one of the most complex and vexing challenges in the global economy. Inequality of opportunity. Inequality across generations. Inequality between women and men. And of course, inequality of income and wealth. They are all present in our societies and - unfortunately - in many countries they are growing. The good news is we have tools to address these issues, provided we have the will to do so. Despite the political difficulty of implementing reforms the payoffs for growth and productivity are worth the effort» [11]. Experts from both international institutions concluded that there is an inverse proportion between the inequality of income distributions and the level of economic growth: deepening inequality leads to a slowdown of economic growth. According to OECD analysts, the GDP of OECD member countries could be up $8.5 \%$ if it weren't the widening gap between the poor and the rich over the last 25 years [14]. As reported by the German Institute for Economic Research in Berlin (Deutsches Institut für Wirtschaftsforschung) for Germany, this means a loss of a potential $€ 40$ billion a year [3].

According to some experts there are two main reasons for this situation: firstly, the existence of so-called «tax havens» - offshore zones that allow largecap owners to avoid paying taxes, and, secondly, the inefficiency or unwillingness of national governments and the world community in regulating this issue. As stated in Oxfam report, from $2000^{\text {th }}$ to $2014^{\text {th }}$, the number of offshore investments increased fourfold, with nine of the world's ten largest corporations represented in at least one offshore [2]. Pursuant to various estimates, twentyone to thirty-two trillion dollars are hidden in offshore, and $98 \%$ of all financial transactions in the world are now speculative [36]. And this is provided that today the representatives of large cap pay the lowest taxes for the last decade. A $0.5 \%$ increase in taxation for one percent of the world's richest people will provide 262 million children with free education or 3.3 million people with quality health services [21].

In turn, representatives of the expert community have repeatedly pointed to the reluctance or inability of national governments and international institutions to solve this issue. The members of the Club of Rome Ernst von Weizsaecker and Anders Wijkman in their report «Come On! Capitalism, Short-termism, Population and the Destruction of the Planet» in $2017^{\text {th }}$ stated that corporations, which avoid taxes payment constantly say they don't violate any laws. It often is - then it is necessary to change the laws [36]. However, real-world experience shows, that even after resonant scandals, «quiet harbors» for businesses remain intact. After all, the world broke into an era of «egocentrism», which is «characterized by the authoritarian behavior of political leaders and States, the radicalization of public sentiment, neo-isolationism, political decentralization, etc. » $[25]$. The consequence of such an «egocentric» policy is the asymmetric 
distribution of resources in society: the excess of capital in the fictitious, but super-profitable spheres, and its scarcity in the strategic directions of the longterm development of the States. In keeping with the World Inequality Report, since the 1980s, «over the past decades, countries have become richer but governments have become poor» as a result of the State property privatization [1, p. 10-11].

It is worth noting that in addition to mention above problems, in our opinion, there is a third cause of total economic inequality - the systematic business and politics interpenetration and the emergence of the newest phenomenon - the so-called «global corruption». The financial-political groups' formation is a result of the merger of political and business interests and it is inherent not only for unstable institutional environments but also for States with stable democratic traditions and developed economic and political systems. But, with less destructive consequences for society, which is conditioned by the existing «historical immunity» and permanent «preventive vaccination» in the relations system «State-corporations - civil society».

In the United States and Western Europe processes of aggressive business political expansion took place at the turn of the XIX-XX centuries. In particular, the American researcher James Bradford DeLong draws some parallels between modern oligarchs in the post-Soviet space and American «robber barons» of those days. In his view, the «barons» of those days, like their contemporary «colleagues,» earned their wealth in coal, steel, and railroads during the great commodity boom before World War I [6, p. 179]. And they were also characterized by an unbridled desire to influence State management decisions process, thereby guaranteeing the viability and prosperity of their own businesses. However, the period of big business representatives' domination in the Political Power sphere in the USA was short enough and lasted from 1865 to 1896. In the future, especially during the presidency of Franklin D. Roosevelt, the large-cap owners were sidelined by the newly formed political elites. After World War II, military and corporate elites reinforced their influence on the on the public administration process [17, p. 272].

It is worth noting that in spite of some similarities between «American barons» of those days and the modern oligarchs, in our view, there are also significant differences due to their origin and functioning conditions: 1) the globalization processes and global market formation; 2) increased competition level in a «full world» conditions [5]. Relating to history, we can see that the «robber barons», despite their «predatory» business behavior and attempts (sometimes effective) to influence on public policy, all their acquired wealth (which, mainly, was lost in the following generations: their estates in Newport, Rhode Island (1960-70) sold for $2 \%$ of the original price) was invested in the development of their own country, which gave impetus to the development of the State's economy in general. On the other hand, in globalized world the modern oligarchs 
are characterized by a different feature-outputting money from the country through various offshore and it's further investing in «friendly» to themselves economies and States linked with them by «global corruption». In the «full world» the main source of key-corporations' extra profiteering become not as much innovative activity, that produces new quality management models and revolutionary technologies, as a tough fight with competitors for redistribution of existing spheres and cash flows through formalized/unformalized instruments of influence. Experience has shown that corporate claims from businesscompetitors are often satisfied by third side - citizens of States, which ultimately leads to the widening gap between rich and poor. And not only economic but social too. After all, as the saying goes, «the level of freedom is determined by the standard of living».

The problem of formation and financial-political groups' functioning in stable and unstable institutional environment (in particular in Ukraine and the Russian Federation) had been paid much attention in a number of the Ia. Teleshun's scientific works $[27,28,29,31]$. Where is noted that under certain conditions, financial-industrial groups lose their exclusively economic traits and acquire new features that give reason to classify them as financial-political groups. Such corporate groups are characterized by a combination of economic, political and administrative components to satisfy private and business interests. However, not less interesting issue is the relationship between the politicaleconomic groups' functioning in the framework of systemic instability and the phenomenon of «global corruption». It is noteworthy that corruption as a phenomenon characterized by the systematic «use of public instruments for private interests» [18] is the cementing foundation of current financial-political groups' functioning.

Before turning to the "global corruption» phenomenon, it should be mentioned that in States with unstable institutional environment, in our opinion, there are two development scenarios of interconnection between financial-industrial groups and public authorities: 1) full subordination of the financial-industrial groups' political and economic activity to the will of the State- «occupation of business» (for example in the Russian Federation); 2) «seizure of power» by financial-industrial groups and their further transformation into financial-political groups (for example in Ukraine).

In the first scenario, the executive branch becomes the center of decision-making and controls the national party system through a well-organized presidential party. Power center with the help of a wide range of tools dictates its will to the representatives of financial-industrial groups, various associations, trade unions, federations, etc. Eliminate the existence of corporations and other powerful organization outside this system. In essence, the State is «occupying» space between itself, society and financial-and industrial groups. Instead, according to the second algorithm, patron-client relationships penetrate the 
triangle «State-financial-industrial groups-society», that is leading to the gradual merger of big business representatives and political classes with the dominance of financial-industrial groups and their subsequent transformation into financial-political ones. Primary financial-political groups' incessant wrestle for state power becomes the main instrument of reproduction of this system [30, p. 118-119].

The rooting of informal structures in the State institutions system: government, parliament, and the judiciary lead to a significant spread of corruption in the State, what transform State institutions in the profit tools for a small group of people. Under such system a qualitative indicator of the of public policy effectiveness becomes not the social result for the citizen, but the politician\official's ability to maximum «capitalize» their position and functions in the system «State-financial-political groups - society - citizen».

In both scenarios, the participation of political-economic groups in the foreign policy of the Sate plays an important aspect of their activity in the system «State-financial-political groups». But these relationships are diametrically opposite. With the dominance of business groups («seizure of power»), the State becomes an instrument of foreign economic interests' realization of financialpolitical groups. In this case the first persons of the State assume the lobbyists' function of domestic political-economic groups in the national markets of other countries. For example the President of Ukraine Viktor Yushchenko had supported «Industrial Union of Donbass» corporation in the purchase «Huta Stali Częstochowa» (now «ISD-Huta Chęstochowa») in Poland and "Group $\mathrm{DF} »-$ «Nitrofert» in Estonia. Undoubtedly, the support of big national business, by establishment, in the markets of other countries is not a criminal activity, vice versa - a logical and obligate step of any democratic and industrially powerful State. However, unlike the practice widespread in countries with longstanding democratic traditions, the benefits of domestic big business promoting to foreign markets is received not by the State in general, but by specific individuals integrated into political-economic relations.

It is worth noting that in the framework of systemic instability and «selective justice» not only domestic businesses are inclined to use personal ties with the authorities. In particular, there are specific issues regarding the activities of the gas company «Geo Alliance Group», owned by Ukrainian billionaire Viktor Pinchuk (owner of the international investment advisory group «EastOne Group») and the Swiss-Dutch company «Vitol Group». Currently, the «Geo Alliance» group has eleven companies and sixteen hydrocarbon deposits located in Ukraine [10]. However, in this case it is not so much interesting the fact of the current functioning of the company as the history of its formation. Ten deposits were provided to V. Pinchuk outside the tender in September-November $2004^{\text {th }}$ (several months before the end of the Leonid Kuchma's (V. Pinchuk's father-in-law) presidential term of office), and seven in July 2007. In $2012^{\text {th }} 25 \%$ 
of «Geo Alliance» shares were acquired by Vitol Group and in $2017^{\text {th }}$ its share increased to $50 \%$. According to analysts, the change in the ownership structure of «Geo Alliance» was due to the following factors: 1) long-lasting friendly relations V. Pinchuk with Ian R. Taylor-Chairman and former Global CEO of «Vitol Group»; 2) the necessity to increase investment into the development of deposits; 3) the desire to create an additional protective layer around the owner of «EastOne Group» and his businesses [23], due to the loss of a strong administrative resource in the shape of L. Kuchma and later attempts to return the deposits to State ownership in $2007^{\text {th }}$ [33] and $2017^{\text {th }}$ [34].

It is interesting that to the Interpipe Research, Industries \& Investment Group (in the list of the TOP-10 largest manufacturers of seamless tubes and ranked 3 rd in the volume of production of all-rolled railway wheels in the world), which is part of the «EastOne Group», wasn't imposed sanctions by Russia, unlike Pinchuk's other companies and himself. After all, according to some testimonies, the Interpipe's products are actively used by the Russians to increase oil and gas production and rail transportation [32]. Moreover, according to Andrii Derkach (a People's Deputy of Ukraine 1998 - till now), V. Pinchuk cooperated with the KGB (State Security Committee of the USSR) [19]. Herewith the «Victor Pinchuk Foundation» and "EastOne» are powerful donors to the «Clinton Foundation» (\$ 8.1 million in 2014) [13].

In 2016 «EastOne Group» were interested in acquiring the assets of the gas-producing company «KUB-GAZ», but gave way to «Burisma Group» and its owner Mykola Zlochevsky (Minister of Ecology and Natural Resources from July $2,2010^{\text {th }}$ to December $9,2010^{\text {th }}$ ). This gas company is linked to a scandal over the name of Hunter Biden, son of $47^{\text {th }}$ U.S. Vice President Joe Biden. In addition to H. Biden, the Board of Directors of «Burisma Holdings» also included another famous personality-Aleksander Kwaśniewski (President of Poland 1995-2005) [35].

Another step towards establishing «friendly» relations between the establishment of Western States and representatives of financial-political groups is the acquisition of high-value real estate in these countries. On the one hand, it is a significant investment in the economies of Europe and North America, on the other - a proven way to legalize the «dirty» funds of financial-political groups. Thus, Rinat Akhmetov, the richest man in Ukraine and the owner of «SCM Holdings Limited», acquired one of the most expensive villas in the world at the end of $2019^{\text {th }}$ at the Italian company «Campari Group» - Villa Les Cedres (France) for 200 million euros. The «SCM» group evaluates this asset as a longterm investment alongside other real estate in Europe and North America [24]. Representatives of the financial-political group «Privat» Ihor Kolomoisky and Gennadiy Bogolyubov also own significant assets, including in the USA: 55 Public Square Building (Cleveland, Ohio) for \$ 46.5 millions; One Cleveland Center (Cleveland, Ohio) - \$ 86.3 millions; AECOM Building (Cleveland, Ohio) - \$ 
46.5 millions; partly Crowne Plaza Hotel (Cleveland, Ohio); Stemmons Towers (Dallas, TX); CompuCom System Headquarters (Dallas, Texas); PNC Plaza (Louisville, Kentucky) - \$ 77 million; Huntington Building (Cleveland, Ohio) - \$ 18.5 million; CC Metals and Alloys LLC (Calvert, Kentucky) ferro-silicon plant $-\$ 188.1$ million; Corey Steel (Cicero, Illinois) metallurgical plant $-\$ 43.5$ million, etc. [16]. The money for the acquisition of these assets was withdrawn from Privatbank (through 19 anonymous companies in the US and PrivatBank Cyprus) for ten years (2006 to 2016) and the total amount of money laundered was $\$ 470$ billion. It is worth mentioning Dmytro Firtash and his close relationship with the United Kingdom establishment, in particular the Conservative and Unionist Part (in favor of which D. Firtash donated) and Boris Johnson personally. And a lawsuit regarding the sale and purchase of the historic Brompton Road tube station [15].

Instead, with the domination of the State («occupation of business»), financial-political groups become an additional tool for influencing the geopolitical map of the world. Where in addition to the traditional methods of the States' struggle for spheres of influence, the latest tools of «hybrid war» and «hybrid friendship» are used. In such circumstances, financial-political groups become the modern equivalent of the Trojan horse. In particular, it is a corruption scandal related to "caviar diplomacy» in the Parliamentary Assembly of the Council of Europe and found some PACE deputies implicated in corruption actions for the benefit of Azerbaijan and other States [22]. Another example of financial-political groups' indirect influence of one State on the political process of another is the results of the International Consortium of Investigative Journalists investigation. According to published information, Russian billionaire Yuri Milner (co-owner and former chairman of the board of directors of the Russian Internet company «Mail. Ru Group») acquired about 10\% of Facebook shares and $5 \%$ of Twitter shares, which allowed him to be included in the list of the most influential people of the IT industry in the world. Y. Milner's funds for this financial transaction were provided by the State-owned VTB Bank (with a minimum interest rate and unequal collateral) and «Gazprom Investholding» through Bermuda-based law firm «Appleby». This percentage of ownership of the global IT giants directly allows Y. Miller and representatives of the financialpolitical group to which he belongs: 1) to influence the policy of these IT corporations (including during elections); 2) to contact the political and economic elites of the United States of America. Direct access to the «body» of the American establishment allowed Y. Milner to become an investor in Jared Kushner's (sonin-law of U.S. President Donald Trump and his senior advisor since January 2017) fintech company- «Cadre» [20]. In such circumstances, the question of one State's influence and interference in the political processes of another through the establishment of these countries remains open. 
It is worth noting that in the second scenario («occupation of business»), the State can exert its influence not only through the intermediary of financialpolitical groups' representatives, but also with the help of their «colleagues» on capital with «low social responsibility»: criminal gangs. According to a report by international security expert Mark Galeotti for the European Council on Foreign Relations, criminal gangs created by migrants from the Russian Federation in the early 1990 s became an additional tool for Russia's pressure on both its «opponents» and «allies» in the international arena [9]. Russian Organized Crime (RBOC) is used by intelligence agencies and law enforcement agencies in Europe and North America to communicate with the «useful» people (through buying/ blackmailing/intimidating), legalizing "dirty» money, strengthening and expanding the cyber-spy network, promoting own agents of influence in the public authorities, eliminating «inconvenient» people etc.

Interventions in internal affairs of sovereign States through the mediation of financial-political groups and/or representatives of criminal circles (as well as any agents of influence) that are integrated into the system of «transit corruption» are, oddly enough, similar. After all, big business in modern Russia (and not only in Russia, but also in other States of the post-Soviet space) was formed by four main groups: 1) the members of the nomenclature-representatives of the Communist Party of the USSR, the komsomol (including the leaders of the Center for Scientific and Technical Creativity of the Youth) or non-industrial State structures; 2) the «red directors»-heads of Soviet enterprises; 3) the shadow economy rustlers - were engaged in the informal purchase and sale of goods, not necessarily on a large volume; 4) the «new Russians» - created capital without relying on the resources of the previous groups, mostly by dubious or illegal (criminal) means [8, p. 53). So, one of the main sources of primitive accumulation of capital in the post-Soviet space was shadow/half-shadow and illegal activity. However, this isn't solely the «know-how» of the post-Soviet space. As noted above, the vast majority of States underwent this historic process at the turn of the eighteenth-nineteenth centuries, but absolutely in other circumstances.

Of course, the opinion of the expert community may be that this is exclusively a problem for individual countries and regions of the world at some stage of their historical development. Of course, there can be the opinion in the expert community that this is exclusively a problem for individual countries and regions of the world at definite stage of their historical development. However, in our opinion, this phenomenon is more global. The penetration of «businesspredatory» behavior with «illegal taste» in the system of government and borrowing it by the political class (including the ruling one) gradually makes it a commendation in the eyes of citizens. In such circumstances, corrupt and illegal activity becomes not only not condemned, but also desirable and socially recognized as effective. As noted by a well-known Ukrainian scientist, adviser to 
several Presidents of Ukraine Sergii Teleshun: «today the word steal-becomes a compliment to the effectiveness of governance», both for representatives of the ruling class and for all society [26]. And zero corruption tolerance among the representatives of the political class exists, provided that their «fate» is absent in a particular corruption scheme. And this type of behavior is not limited to the territorial borders of States. After all, any entrepreneurial activity is characterized by a desire to amalgamation and capture new markets, especially if there are strong rears represented in the form of «controlled» or at least «friendly» power in the «State- Metropole» of their own business. The conquest of new markets for goods and services is accomplished through the usage of well-recommended tools, which in a tactical perspective are often more effective (in less than 30 years 111 official billionaires have appeared in the post-Soviet space [4]) than their democratic and legal analogues in countries with advanced economic and political systems.

However, it should be understood that this behavior of modern «barons» and «magnates» is absolutely to liking of the major part of economic establishment representatives of highly developed countries. Because in a «full world» close cooperation with representatives of corrupt financial-political groups are: 1) one of the fastest and conditionally legal ways to get an extra-profit; 2) the possibility to change the existing status quo in the world market for its own benefit. There is no exception for representatives of the political class who, through contacts with foreign financial-political groups receive either a financial gain or political dividends both for themselves and for their own political project. And the issues of morality and the conformity of their actions with democratic principles and procedures are becoming secondary. As a result, there are numerous scandals related to the financing and support of individual politicians and political parties by Russian financial-political groups in other States: the scandal connected with Marine Le Pen and the «National Rally» (until June 1, 2018, the National Front) in France over the lending of the "National Front» in $2014^{\text {th }}$ to the amount of 11 million euros by Russian banks affiliated with the Kremlin; the scandal linked to «Freedom Party of Austria» and it's leader HeinzChristian Strache and his negotiations toward Russian financial and media support in the elections in $2017^{\text {th }}$; the support for Russia's financial-political groups by right-wing populist parties in Germany and Poland; the attempts to influence the results of the 2016 US presidential election and more. In this context, it is worth remembering the famous expression of the 1st US Secretary of the Treasury Alexander Hamilton: «There is no virtue in America. That commerce which presided over the birth and education of this states has fitted their inhabitants for the chain... the only condition they sincerely desire is that it may be a golden one». With just one clarification, the vast majority of the world is ready to be on this «gold chain». After all, «God is Dead» and was replaced by a new 
god-Midas, who is both a value and a measure of success and the titular myth of the modern world.

With the spread of the «Gold Rush Virus» an increasing number of people are faced with a difficult choice: either to adopt new principles and rules of behavior while remaining in the competitive environment, or to find themselves outside the board of contemporary world socio-economic and political mainstream. According to the Global Social Mobility Index (2020), none of the G7 countries ranked in the Top-10 with the highest "positive bandwidth» from one to another socio-economic layer [12]). The top five include Scandinavian countries: Denmark, Norway, Finland, Sweden and Iceland. Of the Group of Seven, Germany is the most socially mobile ( $11^{\text {th }}$ position), slightly behind France $\left(12^{\text {th }}\right)$. Canada $\left(14^{\text {th }}\right)$ and Japan $\left(15^{\text {th }}\right)$ also included in the TOP-20. Other countries: the United Kingdom $\left(21^{\text {th }}\right)$, the United States $\left(27^{\text {th }}\right)$ and Italy $\left(34^{\text {th }}\right)$ didn't reach the top twenty at all. And these are the G7 States, which are in many aspects the world benchmark and legislator of existing rules and forms of human coexistence. However, it should be understood that even those countries that in the top ranking in social mobility index don't exist outside the world market and formed system of international relations. They are also hostage to the "global corruption» and regional financial-political groups' will. Suffice it to recall the conflict over the «Nord Stream 2» gas pipeline. The prolonged Denmark resistance against gas pipeline to be laid in its exclusive maritime economic zone has had a fiasco under systematic pressure from Russia and Germany and with the quiet indulgence of France and other EU member countries. Democratic principles and procedures have given way to economic interests and political expediency.

Admittedly, this situation is of concern not only in the scientific and partly establishment environment, but also in some representatives of big business, mainly in the so-called "old money» of Western countries. Because excessive public attention to this issue, even in the «old» democracies, can lead to a radical revision of the place and role of the large-cap owners in the new model of social contract. And this is a direct threat to the representatives of big business and the existing order of things. In particular, outstripping the autumn protests in New York and other cities in the United States (Occupy Wall Street, in the summer of 2011) was created the movement of millionaires for high taxes. One of the initiators of this movement was U.S. billionaire W. Buffett, who called on the United States Congress to raise taxes for the richest individuals and companies to support reducing their own budget deficits. The most powerful support for the Warren Buffett's initiative was received in the European Union countries: one of the richest French women Liliane Bettencourt (owner of «L'Oreal») together with the owners of the largest French companies ( AAccor», «Air France-KLM», «Arevz», «Citroen», «Danon», «Fimalac», «Orang», «Peugeot»», «Societe Generale», «Total», etc. ) requested the Government to introduce an additional levy for the rich to improve the economy; a similar step was taken by the Italian 
multimillionaire Luca Cordero di Montezemolo (who heads the car holding company «Ferrari SpA»), proposing to additionally tax compatriots with annual income of 5-10 million of euros or more. This initiative was joined by wealthy Germans who founded the organization «Rich for Capital Tax» («Vermögende für eine Vermögensabgabe») and appealed to the Federal Chancellor of the Federal Republic of Germany Angela Merkel to reduce the gap between the poor and the rich [7]. And thus «adjust» the existing social contract between the authorities, business and civil society.

\section{Conclusions}

King Midas's ability to turn everything into gold was both his gift and a curse. The curse that condemned him to starvation and loneliness. In turn, the "gold rush» virus, the «flexibility» of democratic principles and the "collective Midas» are the gift-curses of the 21st century. In this case the State becomes not a service institution which help the citizens, but a club for the interests of shareholders of corporate corruption. Exemption from the "golden gift» can be found not in the Pactolus River, but in the implementation of a new effective model of public administration that would take into account the interests of the State, key corporate actors, civil society and the individual. Only the creation of an effective legal framework, transparent access of civil society to the State's institutions and mechanisms for controlling the resources distribution, not only at the level of national States, but also at the level of the world community, will ensure the sustainable socio-economic, political and democratic development of humanity.

\section{References:}

1. Alvaredo F., Chancel L., Piketty Th., Saez E., Zucman G. (2018). World Inequality Report. World Inequality Lab. Available at: https:// wir2018.wid. world/files/download/wir2018-summary-english. pdf (accessed April 30, 2020)

2. An economy for the 1\%, 2016. Oxfam Briefing Paper. Available at: https://oi-files-d8-prod. s3.eu-west-2.amazonaws. com/s3fs-public/ file_attachments/bp210-economy-one-percent-tax-havens-180116en_o.pdf (accessed May 27, 2020)

3. Bach S. (2018). Die Erbschaftsteuer ist die beste «Reichensteuer». DIW Berlin.Availableat:www.diw.de/documents/publikationen/73/ diw_01.c. 608705.de/18-49-4.pdf (accessed July 27, 2020)

4. Billionaires - The Richest People in the World, 2019. Forbes. Available at: www. forbes. com/billionaires/\# 2f9940fd251c (accessed April 30, 2020).

5. Daly E.H. (2005). Economics in a Full World. Scientific American, US: «Springer Nature», pp. 100-107. 
6. DeLong B. (2002). Robber Barons. Essays on the World Economy: Outstanding World Economists at the Carnegie Moscow Center. Moscow: Gendalf: 179-208.

7. Denkov D. (2011). Akhmetov and Co didn't support Western millionaires. Ekonomichna Pravda. Available at: www. epravda. com. ua/ publications/2011/09/7/297317/ [in Ukrainian], (accessed June 27, 2020)

8. Fortescue S. (2008). Russian oil barons and metal magnates. The oligarchs and the State in transition. Moscow: Stolitsa-print, P. 379 (in Russian).

9. Galeotti M. (2017). Crimintern: How the Kremlin uses Russia's criminal networks in Europe, European Council on Foreign Relations. Available at: www. ecfr. eu/page/-/ECFR208_-_CRIMINTERM_HOW_RUSSIAN_ORGANISED_CRIME_OPERATES_IN_ EUROPE02.pdf (accessed May 30, 2020)

10. Geo Alliance Group-Companies. 2020. Available at: https://geoalliance. com. ua/en/ (accessed April 15, 2020)

11. Georgieva K. 2020. Reduce Inequality to Create Opportunity, IMF Blog. Available at: https://blogs. imf. org/2020/01/o7/reduce-inequality-to-create-opportunity/ (accessed June 17, 2020)

12. Global Social Mobility Index 2020: why economies benefit from fixing inequality. (2020). World Economic Forum. Available at: www. weforum. org/reports/global-social-mobility-index-2020-why-economies-benefit-from-fixing-inequality (accessed April 27, 2020)

13. Grimaldi, J.V., Ballhaus R. (2015). Clinton Charity Tapped Foreign Friends. The Wall Street Journal. Available at: www. wsj. com/articles/clinton-charity-tapped-foreign-friends-1426818602 (accessed April 27, 2020)

14. Karapata, M. (2018). Is it a dangerous gulf between rich and poor in the global economy, Deutsche Welle. Available at: https://p. dw. $\mathrm{com} / \mathrm{p} / 2 \mathrm{w} 7 \mathrm{kr}$ [in Ukrainian], (accessed April 27, 2020)

15. Kovach, O. (2020). Lawsuit in London sheds light on Firtash's ties with British leadership. Radio Svoboda. Available at: www. radiosvoboda. org/a/30469908.html [in Ukrainian], (accessed April 27, 2020)

16. Martinenko, D. (2019).«Property of Kolomoisky and Bogolyubov in the USA. Privatbank discloses US assets to oligarchs». Radio Svoboda. Available at: www. radiosvoboda. org/a/schemes/29984753.htm l? fbclid=IwARoBX4Kta3waZjJnRPphr4lJz_-NA-pYEcJsxgNaF4yUUhElze2oqbZ98yA [in Ukrainian], (accessed April 27, 2020)

17. Mills C.W. (1956). The Power Elite. New York: Oxford University Press, P. 423. 
18. Minakov M. (2020). «Oligarchic clans don't understand how to live under Zelensky». Vesti. ua. Available at: https://vesti. ua/politika/ oligarhicheskie-klany-ne-ponimayut-kak-zhit-pri-zelenskom-filosofminakov [in Russian], (accessed April 27, 2020)

19. MP Derkach stated that Pinchuk was a KGB agent, businessman's representatives deny this. (2019). Gordon. Available at: https:// gordonua. com/ukr/news/politics/-nardep-derkach-zajaviv-shchopinchuk-buv-agentom-kdb-predstavniki-biznesmena-zaperechujuttse-1479599.html [in Ukrainian], (accessed April 27, 2020)

20. Offshore Trove Exposes Trump-Russia Links And Piggy Banks Of The Wealthiest 1 Percent. (2017). International Consortium of Investigative Journalists. Available at: www. icij. org/investigations/ paradise-papers/paradise-papers-exposes-donald-trump-russialinks-and-piggy-banks-of-the-wealthiest-1-percent/ (accessed April 27, 2020)

21. Public Good or Private Wealth. (2019). Oxfam Inequality Report. Available at: https://oxfam. app. box. com/s/fgmeuz1jrd9e1xrkrq59e37tpoppqupo/file/385579400762 (accessed April 27, 2020)

22. Report of the Independent Investigation Body on the allegations of corruption within the Parliamentary Assembly. (2018). Council of Europe. Available at: http://assembly. coe. int/Communication/ IBAC/IBAC-GIAC-Report-EN.pdf (accessed April 27, 2020)

23. Ryasnij, D. (2020). Pinchuk sells gas business: what happened and why it's not so good for the industry. Ekonomichna pravda. Available at: https://www. epravda.com. ua/publications/2020/02/3/656532/ [in Ukrainian], (accessed April 27, 2020)

24. SCM Holdings Limited announces acquisition of real estate asset. 2020. SCM Holdings Limited. Available at: www. scmholdings. com. cy/scm-holdings-limited-announces-acquisition-of-real-estate-asset /?fbclid=IwAR1FGt9sCr4HcDOImc_tyoPWWcIigvhnQJOjtg8XqL1p ImbnFLPTrQxBs_Q (accessed April 27, 2020)

25. Teleshun, S. O. (2017). The social outcome of reforms can be a litmus test for the prospect of a «Ukrainian project» and the maturity of a nation, Ukrinform. Available at: www. ukrinform. ua/rubricpolytics/2194400-sergij-telesun-doktor-politicnih-nauk. html [in Ukrainian], (accessed April 27, 2020)

26. Teleshun, S. O. (2019). Puls. 112.ua. Available at: https://video-ua. 112. ua/puls-pisliamova-efir-vid-15012019-287486.html [in Ukrainian], (accessed April 27, 2020)

27. Teleshun, Ia. (2016). Features of the financial-political groups' functioning in the system of public policy: realities of Ukraine. Kyiv. 
Bulletin of Igor Sikorsky Kyiv Polytechnic Institute. Political Science. Sociology. Law. 1/2 (29/30): 137-142 [in Ukrainian]

28. Teleshun, Ia. (2017). Mass media as a tool for the financial-political groups' struggle: the realities of Ukraine. Kyiv. Scientific journal of National Pedagogical Drahomanov University. Political Science, Series 22, 22: 57-64 [in Ukrainian]

29. Teleshun, Ia. (2017). Clientelism as a component of the of financialpolitical groups' functioning. Vinnytsia, «Political Life». 3: 79-83 [in Ukrainian]

30. Teleshun, Ia. (2018). Financial-political groups in an unstable institutional environment. Kyiv: Taras Shevchenko National University of Kyiv. Dis...kand. polit. nauk: 23.00.02. URL: http://scc. univ. kiev. ua/upload/iblock/2b6/dis_Teleshun\%20Ya. S..pdf [in Ukrainian], (accessed September 27, 2020)

31. Teleshun, Ya. (2016). Some aspects of financial-political groups' activity during political crisis 2014-16, Evropský politický a právní diskurz (European political and law discourse), Družstvo «JižníPalmíra», Brno: JižníPalmíra, družstvo, Vol. 3, Issue 5: 69-74.

32. Blood trade according to Pinchuk's plan: why Kuchma was returned to Minsk talks. (2019). OBOZREVATEL. Available at: www. obozrevatel. com/ukr/society/plan-pinchuka-navischo-kuchmu-povernuliv-minski-peregovori. htm [in Ukrainian]

33. Resolution in the case № K-31103/o6 of the Supreme Administrative Court of Ukraine, May 28, 2008. State register of court decisions. Available at: http://www. reyestr. court. gov. ua/Review/2970177 [in Ukrainian]

34. Resolution in the case № 66655555 of the Pechersk District Court of Kyiv, May 11, 2017. State register of court decisions. Available at: https://youcontrol. com. ua/catalog/court-document/66655555/ [in Ukrainian]

35. Vogel P. Kenneth, Mendel Iu. 2019. Biden Faces Conflict of Interest Questions That Are Being Promoted by Trump and Allies», The New York Times. Available at: www. nytimes. com/2019/05/01/us/politics/biden-son-ukraine. html

36. Weizsäcker von E.U., Wijkman A. (2018). Come On! Capitalism, Short-termism, Population and the Destruction of the Planet. New York: Springer, P. 220.

\section{Список посилань}

1. Alvaredo F., Chancel L., Piketty Th., Saez E., Zucman G. (2018). World Inequality Report. World Inequality Lab. URL: https://wir2018.wid. world/files/download/wir2018-summary-english. pdf (дата звернення: 30.04.2020). 
2. An economy for the 1\%, 2016. Oxfam Briefing Paper. URL: https:// oi-files-d8-prod. s3.eu-west-2.amazonaws. com/s3fs-public/file_attachments/bp210-economy-one-percent-tax-havens-180116-en_o. pdf (дата звернення: 20.04.2020).

3. Bach S. (2018). Die Erbschaftsteuer ist die beste «Reichensteuer». DIW Berlin. URL: www. diw. de/documents/publikationen/73/ diw_01.c. 608705.de/18-49-4.pdf (дата звернення: 30.05.2020).

4. Billionaires - The Richest People in the World, 2019. Forbes. URL: www. forbes. com/billionaires/\#2f9940fd251c (дата звернення: 30.05.2020).

5. Daly E.H. (2005). Economics in a Full World. Scientific American, US: «Springer Nature» P. 100-107.

6. DeLong B. (2002). Robber Barons. Essays on the World Economy: Outstanding World Economists at the Carnegie Moscow Center. Moscow: Gendalf: 179-208.

7. Дєнков Д. Ахметов і Ко не підтримали західних мільйонерів // Економічна правда. URL: http://www. epravda. com. ua/ publications/2011/09/7/297317/ (дата звернення: 30.05.2020).

8. Фортескью С. Русские нефтяные бароны и магнаты металла. Олигархи и государство в переходный период; пер. с англ. Т. Новикова. М.: Столица-принт, 2008. - 379 с.

9. Galeotti M. (2017). Crimintern: How the Kremlin uses Russia's criminal networks in Europe, European Council on Foreign Relations. URL: www. ecfr. eu/page/-/ECFR208_-_CRIMINTERM_-HOW_ RUSSIAN_ORGANISED_CRIME_OPERATES_IN_EUROPEO2.pdf (дата звернення: 30.05.2020).

10. Geo Alliance Group-Companies. 2020. URL: https://geo-alliance. com. ua/en/ (дата звернення: 15.04.2020)

11. Georgieva K. 2020. Reduce Inequality to Create Opportunity, IMF Blog. Available at: https://blogs. imf. org/2020/01/o7/reduce-inequality-to-create-opportunity/ (дата звернення: 17.08.2020).

12. Global Social Mobility Index 2020: why economies benefit from fixing inequality. (2020). World Economic Forum. Available at: www. weforum. org/reports/global-social-mobility-index-2020-why-economies-benefit-from-fixing-inequality (дата звернення: 17.08.2020).

13. Grimaldi, J.V., Ballhaus R. (2015). Clinton Charity Tapped Foreign Friends. The Wall Street Journal. URL: www. wsj. com/articles/clinton-charity-tapped-foreign-friends-1426818602 (дата звернення: 20.08.2020).

14. Карапата М. Чи небезпечна прірва між багатими й бідними для світової економіки. Deutsche Welle. URL: https://p. dw. com/ p/2w7kr (дата звернення: 20.09.2020). 
15. Ковач О.Судовий позов у Лондоні проливає світло на зв'язки Фірташа з британським керівництвом. Paдio Свобода. URL: https://www. radiosvoboda. org/a/30469908.html (дата звернення: 17.08.2020).

16. Мартиненко Д. Майно Коломойського та Боголюбова у США. «Приватбанк» розкрив американські активи олігархів. Paдіо Свобода.-URL: https://www. radiosvoboda. org/a/ schemes/29984753.html?fbclid=IwARoBX4Kta3waZjJnRPphr4 lJz_-NA-pYEcJsxgNaF4yUUhElze2oqbZ98yA (дата звернення: 17.08.2020).

17. Mills C.W. (1956). The Power Elite. New York: Oxford University Press, P. 423.

18. Минаков М. «Олигархические кланы не понимают, как жить при Зеленском»// VESTI.ua. URL: https://vesti. ua/politika/ oligarhicheskie-klany-ne-ponimayut-kak-zhit-pri-zelenskom-filosofminakov (дата звернення: 17.08.2020).

19. Нардеп Деркач заявив, що Пінчук був агентом КДБ, представники бізнесмена заперечують це. ГОРДОН. URL: https://gordonua. com/ukr/news/politics/-nardep-derkach-zajaviv-shcho-pinchukbuv-agentom-kdb-predstavniki-biznesmena-zaperechujut-tse1479599.html (дата звернення: 30.05.2020).

20. Offshore Trove Exposes Trump-Russia Links And Piggy Banks Of The Wealthiest 1 Percent. (2017). International Consortium of Investigative Journalists. URL: www. icij. org/investigations/paradise-papers/ paradise-papers-exposes-donald-trump-russia-links-and-piggybanks-of-the-wealthiest-1-percent/ (дата звернення: 20.09.2020).

21. Public Good or Private Wealth. (2019). Oxfam Inequality Report. URL: https://oxfam. app. box. com/s/f9meuz1jrd9e1xrkrq59e37tpo ppqupo/file/385579400762 (дата звернення: 20.09.2020).

22. Report of the Independent Investigation Body on the allegations of corruption within the Parliamentary Assembly. (2018). Council of Europe. URL: http://assembly. coe. int/Communication/IBAC/ IBAC-GIAC-Report-EN.pdf (дата звернення: 20.09.2020).

23. Рясний Д. Пінчук продає газовий бізнес: що сталося і чому це недобре для галузі Економічна правда. URL: https://www. epravda. com. ua/publications/2020/02/3/656532/ (дата звернення: 17.08.2020).

24. SCM Holdings Limited announces acquisition of real estate asset. 2020. SCM Holdings Limited. URL: www. scmholdings. com. cy/ scm-holdings-limited-announces-acquisition-of-real-estate-asset/?f bclid=IwAR1FGt9sCr4HcDOImc_tyoPWWcIigvhnQJOjtg8XqL1pIm bnFLPTrQxBs_Q (дата звернення: 20.09.2020). 
25. Телешун С. О. «Соціальний результат реформ може стати лакмусовим папірцем перспективності «українського проекту» та зрілості нації». УКРІНФОРМ. URL: https://www. ukrinform. ua/rubric-polytics/2194400-sergij-telesun-doktor-politicnih-nauk. html (дата звернення: 25.09.2020).

26. Телешун С.О. Пульс. Післямова. Ефір від 15.01.2019 // 112.ua. URL: https://video-ua. 112.ua/puls-pisliamova-efir-vid-15012019287486.html (дата звернення: 25.09.2020).

27. Телешун Я.С. Особливості функціонування фінансовополітичних груп у системі публічної політики: реалії України. Вісник Національного технічного університету України «Киӥвський політехнічний інститут». Політологія. Соціологія. Право. -К.: «Політехніка», 2016. № 1/2 (29/30). С. 137-142.

28. Телешун Я.С. Засоби масової інформації як інструмент боротьби фінансово-політичних груп: реалії України. Науковий часопис Національного педагогічного університету імені $M$. П. Драгоманова. Серія 22. Політичні науки та методика викладання соціально-політичних дисциилін. Київ, 2017. № 22. C. $57-64$.

29. Телешун Я.С. Клієнтелізм як складова функціонування фінансово-політичних груп. Політичне життя (Political Life). Вінниця, 2017. №3. С. 79-83.

30. Телешун Я.С. Фінансово-політичні групи в нестабільному інституційному середовищі: дис. ... канд.. політ. наук: 23.00.02. Ктїв, 2018. 248 c.

31. Teleshun,Ya.(2016). Someaspects offinancial-politicalgroups'activity during political crisis 2014-16, Evropský politický a právní diskurz (European political and law discourse), Družstvo «JižníPalmíra», Brno: JižníPalmíra, družstvo, Vol. 3, Issue 5: 69-74.

32. Торгівля на крові за планом Пінчука: навіщо Кучму повернули у Мінські переговори. OBOZREVATEL. URL: https://www. obozrevatel. com/ukr/society/plan-pinchuka-navischo-kuchmu-povernuliv-minski-peregovori. htm (дата звернення: 25.09.2020).

33. Ухвала Вищого адміністративного суду України від 28 травня 2008 р., судова справа № К-31103/o6. Єдиний державний реестр судових рішень. URL: http://www. reyestr. court. gov. ua/ Review/2970177 (дата звернення: 25.09.2020).

34. Ухвала Печерського районного суду міста Києва від 11 травня 2017 р., судова справа № 66655555. Єдиний державний реєстр судових рішенъ. URL: https://youcontrol. com. ua/catalog/courtdocument/66655555/ (дата звернення: 25.09.2020). 
35. Vogel P. Kenneth, Mendel Iu. (2019). Biden Faces Conflict of Interest Questions That Are Being Promoted by Trump and Allies», The New York Times. Available at: www. nytimes. com/2019/05/01/us/politics/biden-son-ukraine. html (дата звернення: 10.09.2020).

36. Weizsäcker von E.U., Wijkman A. (2018). Come On! Capitalism, Short-termism, Population and the Destruction of the Planet. New York: Springer, P. 220.

Стаття надійшла до редакциї 14.10.20

(C) Телешун Я.С., 2020 